RESEARCH ARTICLE

\title{
Systematics of genus Garcinia L. (Clusiaceae) in Sri Lanka: new insights from vegetative morphology
}

\author{
W.J. Nimanthika and H.S. Kaththriarachchi" \\ Department of Plant Sciences, Faculty of Science, University of Colombo, P.O.Box 1490, Colombo 03.
}

Revised: 26 November 2009; Accepted: 18 December 2009

\begin{abstract}
The genus Garcinia L. (Family: Clusiaceae) is represented by ten species in Sri Lanka including five endemic species. Systematics of the genus hitherto were primarily based on reproductive morphology. A recent study was carried out in order to evaluate the species limits of Sri Lankan Garcinia using anatomical characters. However, the field identification of Garcinia is challenging due to the presence of unisexual flowers, strict seasonality in flowering and fruiting, and failure to use anatomical characters.
\end{abstract}

The aim of this study was to investigate the relationships among the species and to construct an identification key based on the vegetative morphological characters. Specimens of all representative taxa were sampled from different geographical locations. A total of 97 specimens were collected and similarity and cladistic analyses were performed based on 47 vegetative morphological characters. The results suggest that the sampled species fall into two major groups characterized by leaf morphological features. Major groups can be further divided into subgroups by bark colour and tertiary venation. The overall results demonstrate within species variations of $G$. hermonii and G. terpnophylla highlighting the presence of different varieties. The dichotomous key constructed using conspicuous vegetative characters will be a valuable tool for identification of Sri Lankan Garcinia species in the field. The relationships found in this study provide insights to the phylogeny of the species. The results are congruent with those of the recent anatomical study and revealed the importance of combined multidisciplinary data analysis to elucidate more robust species relationships.

Keywords: Bootstrap, cladistic, Garcinia, phylogeny, strict consensus tree, vegetative morphology.

\section{INTRODUCTION}

Garcinia L. (Clusiaceae) is a pantropically distributed angiosperm genus with high species richness in South
East Asia, and composed of 240 woody tree species ${ }^{1}$. Garcinia belongs to the tribe Garcinieae Choisy, in which the genera Pentaphalangium Warb., Rheedia L., and Tripetalum K. Schum. are included ${ }^{2}$, and has a close relationship with the genus Allanblackia Oliver, which is indigenous to Africa and not found in Sri lanka.

In Sri Lanka the genus is represented by 10 species including five endemic species (G. quaesita, G. zeylanica, $G$. hermonii, G. terpnophylla and G. thwaitesii), three Indo-Sri Lankan species (G. morella, G. echinocarpa and G. spicata), one species cultivated for more than seventy five years ( $G$. mangostana) and an introduced species (G. xanthochymus) which is now considered as a seminaturalized species ${ }^{3}$. The relationships of the above ten Garcinia species and their delimitation has been a subject of controversy (Table 1). Trimen ${ }^{4}$ recognized five species of Garcinia growing in Sri Lanka. Later, Alston ${ }^{5}$ provided a supplement to Trimen's system ${ }^{4}$, incorporating the semi naturalized species G. xanthochymus. Kostermans ${ }^{3}$ recognized nine species. However, during the revision of the 'Handbook to the Flora of Ceylon', ten species have been identified on the basis of morphological characters.

Except for $G$. spicata, the other nine species are distributed in the wet zone of Sri Lanka. Among those $G$. echinocarpa is confined to the montane and submontane regions ${ }^{3}$. G. thwaitesii and G. zeylanica are listed as globally endangered and G. quaesita is listed as globally vulnerable ${ }^{6}$. However, the Sri Lankan Garcinia species have not been assessed for conservation status in the latest IUCN national red data list $(2007)^{6}$.

Garcinia species play a key role as subcanopy species in the lowland wet evergreen forests and submontane 
forests in Sri Lanka. The seedlings of these species are a major constituent of the undergrowth of the lowland wet zone forests. As a result Garcinia species can be successfully used in forest restoration programmes in the degraded lands of the wet zone of Sri Lanka. In addition they can be used in community forestry programmes and in programmes for buffer zone management of forest reserves, as these species have economical value ${ }^{7}$. Xanthones, a group of chemicals found in Garcinia species has important pharmacological effects ${ }^{8,9}$.

The phylogenetic relationships within the ten species of Garcinia studied are far from resolved. The substantial floral diversity of the Garcinia species is very important in field identification ${ }^{2}$. Therefore, the identification keys for the Sri Lankan Garcinia species are mostly based on the flower and fruit morphology ${ }^{3}$.

The flowering and fruiting of Garcinia species are strictly seasonal (from April to June/ July ${ }^{10}$ ) and these species are dioecious. Therefore to identify the species both male and female plants should be sampled.

A comprehensive study has been recently carried out to assess the phylogenetic relationships of the genus using vegetative anatomy ${ }^{11}$, which resolved the species limits of individual species. The anatomical characters however are not very useful and practical in field identification of

Table 1: Comparison of selected taxonomic treatments of genus Garcinia in Sri Lanka

\begin{tabular}{lll}
\hline Trimen $(1893)^{4}$ & Alston $(1931)^{5}$ & Kostermans $(1980)^{3}$ \\
\hline G. cambogia Desr. & G. cambogia Desr. & G. quaesita Pierre \\
G. morella (Gaertn.) Desr. & G. morella (Gaertn.) Desr. & G. morella (Gaertn.) Desr. \\
G. echinocarpa Thw. & G. echinocarpa Thw. & G. echinocarpa Thw. \\
G. terpnophylla (Thw.) & G. terpnophylla (Thw.) & G. terpnophylla (Thw.) Thw. \\
G. spicata (W. \& A.) Hook f. & G. spicata (W. \& A.) Hook f. & G. spicata (W. \& A.) Hook f. \\
& G. xanthochymus Hook f. & G. zeylanica Roxb. \\
& & G. thwaitesii Pierre \\
& & G. hermonii Kosterm. \\
& & G. mangostana L. \\
& G. xanthochymus Hook f. \\
\hline
\end{tabular}

Table 2: Species codes for specimens, the species represented as three letter codes (in capital letters) and the locations are coded as two letter codes (in simple letters). The locality number refers to the number on the map in Figure 1. (PW- Peak Wilderness Sanctuary)

\begin{tabular}{|c|c|c|c|}
\hline Botanical name & Code & Botanical name & Code \\
\hline G. morella (Gaertn.) Desr. & GMO & G. zeylanica Roxb. & GZE \\
\hline G. echinocarpa Thw. & GEC & G. quaesita Pierre & GQU \\
\hline G. terpnophylla (Thw.) Thw. & GTE & G. thwaitesii Pierre & GTH \\
\hline G. spicata (W. \& A.) Hook f. & GSP & G. hermonii Kosterm. & GHE \\
\hline C. rosea & CRO & & \\
\hline Locality & Code & Locality & Code \\
\hline Ritigala & ri & Diyadawa & $\mathrm{di}$ \\
\hline Dehiattakandiya & da & Walankanda & wa \\
\hline Gampaha & ga & Gilimale & gi \\
\hline Bulathsinhala & bu & Kitulgala & ki \\
\hline Kalugala & $\mathrm{ka}$ & Udawalawa & ud \\
\hline Morapitiya & mo & Sinharaja/ Morningside & si \\
\hline Haycock & ha & PW- Maliboda & $\mathrm{mb}$ \\
\hline Kanneliya & $\mathrm{kn}$ & PW- Marathenna & $\mathrm{mt}$ \\
\hline Kottawa & ko & PW- Moray Estate & me \\
\hline 10 Rumassala & $\mathrm{ru}$ & PW- Nallathanniya trail & na \\
\hline Mulatiyana & $\mathrm{mu}$ & Dehiowita & de \\
\hline 12 Rammalekanda & $\mathrm{ra}$ & Ginigathhena & gh \\
\hline
\end{tabular}


these species because of the difficulty in taking transverse/ longitudinal sections of the vegetative parts (stem, leaves) in the field and inconvenience of transportation and usage of necessary scientific instruments to and from the field. The taxonomic treatments for the Sri Lankan Garcinia species by different authors ${ }^{3-5}$ and opportunistic field observations have shown that the species circumscriptions are still contradictory and ambiguous. Therefore, the field identification of these species is challenging and a comprehensive revision of species circumscriptions of the genus Garcinia will be an important contribution to the systematics of the Sri Lankan flora.

The main objective of this study was to carry out a comprehensive systematic survey of Sri Lankan Garcinia species using vegetative morphological features. The specific objectives were to i) Construct the relationships among the Garcinia species using similarity/ distance and phylogenetic analysis methods, ii) Elucidate the species circumscriptions of Sri Lankan Garcinia species based on vegetative morphological characters and iii) Construct species identification keys using vegetative morphological characters to identify Garcinia species in the field.

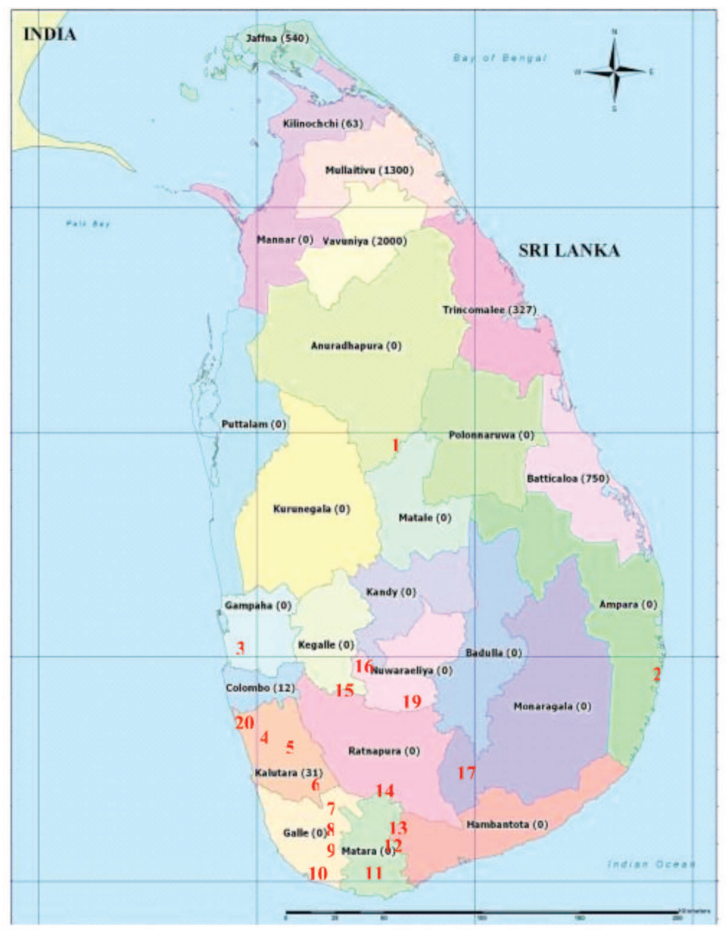

Figure 1: Sampling locations (numbered in red), of the present study. The location codes are in accordance with Table 2.

\section{METHODS AND MATERIALS}

Study species: The indigenous Garcinia species of Sri Lanka, namely G. morella (Gaertn.) Desr., G. echinocarpa Thw., G. terpnophylla (Thw.) Thw., $G$. spicata ( $W$. \& A.) Hook f, G. zeylanica Roxb., G. quaesita Pierre, G. thwaitesii Pierre and G. hermonii Kosterm. were sampled and included in the present study. The two exotic Garcinia species, G. mangostana L. and G. xanthochymus Hook f. were not included due to wide variations in their morphology, which may interfere and cause imprecise relationships within the study group.

Outgroup selection: The closest Sri Lankan relative to the genus Garcinia is the genus Clusia (Clusiaceae) ${ }^{2}$. The genus Clusia is represented by only one species (C. rosea) in Sri Lanka; two specimens of C. rosea were sampled for this study from Ginigathhena.

Taxon sampling: A total of 97 individual plants representing the 8 indigenous Garcinia species were sampled. Efforts were made to attain comprehensive species sampling, representing diverse geographical locations (Figure 1) of each species.

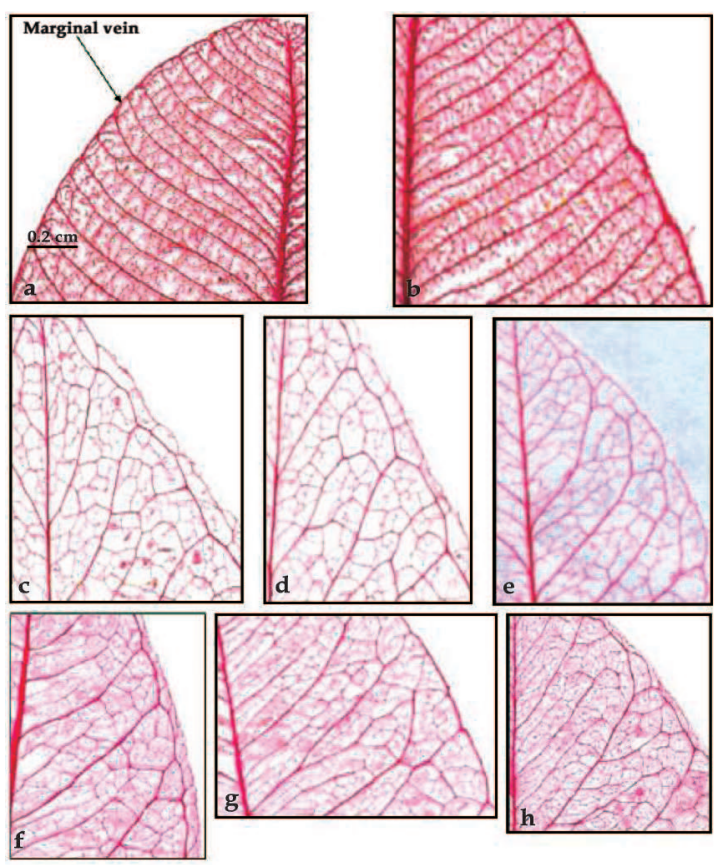

Figure 2: Venation patterns of Sri Lankan Garcinia species. a- G. echinocarpa, b-G. hermonii, c-G. quaesita, d-G. zeylanica, e-G. morella, f- G. terpnophylla, g-G. spicata, h-G. thwaitesii; Two major groups can be identified; leaves with loosely arranged secondary veins $(\mathrm{c}, \mathrm{d}, \mathrm{e}, \mathrm{f}, \mathrm{g}, \mathrm{h})$ and leaves with densely arranged secondary veins $(a, b)$. 
The individual plants were randomly selected from the populations depending on the population size. Mature twigs from sun-exposed portions of the lower crown were harvested from each tree. The sets of leaves for each of the 97 individuals were carefully examined and only intact leaves with no visible damage were selected for analysis, with a sample size of 50 leaves per individual.

The collected specimens were given a species code based on their species name and the location where the specimens were collected (Species codes and the location codes are given in Table 2). Voucher specimens were deposited in the National Herbarium, Peradeniya (Table 3).

Character coding: After careful observation of the sampled specimens, 47 vegetative morphological characters and the respective character states (Table 4), based on the available literature and observations, were selected for the purposes of cluster and cladistic analyses. Among the characters 13 were quantitative and others were qualitative characters. All data were converted into a data matrix.

Leaf clearing: The leaves were cleared for observing distinct veinlet arrangements of different species. The protocol followed for leaf clearing was adapted from that used by Radford et. al. ${ }^{12}$. The original method was modified as follows and used as the most suitable method for the specimens after several trials.

Leaves were placed in a fresh $7 \% \mathrm{NaOH}$ (Sodium Hydroxide) solution, which was replaced with fresh solution daily for $10 \mathrm{~d}$. Leaves were then washed well with water and bleached with $3 \% \mathrm{H}_{2} \mathrm{O}_{2}$ (Hydrogen Peroxide) for $12 \mathrm{~h}$. Finally, leaves were thoroughly washed with water followed by $30 \%$ ethanol for $10 \mathrm{~min}, 50 \%$ ethanol for $10 \mathrm{~min}, 1 \%$ safranin in $50 \%$ ethanol for $2 \mathrm{~min}, 70 \%$ ethanol for $10 \mathrm{~min}, 95 \%$ ethanol for $10 \mathrm{~min}$ and absolute ethanol for $5 \mathrm{~min}$. The leaves were then mounted on glass slides and the leaf venation observed (cleared leaves of the Garcinia species are illustrated in Figure 2).

Cluster analysis: Cluster analysis was performed with PAUP* (Phylogenetic Analysis Using Parsimony) Version 4.0b10 for Macintosh (i book G4/Altivec). The relationships among the Sri Lankan Garcinia species were evaluated using two major clustering methods; Unweighted Pair Group Method with Arithmatic Mean (UPGMA) and Neighbour Joining (NJ) methods. UPGMA analysis was performed for the 97 in-group taxa with randomly initiated seed option. NJ analysis was carried out with randomly initiated seed option and mid point rooting option.
Principal component analysis (PCA): Principal component analysis was carried out using PC-ORD version 4.0, based on correlation matrices of characters. Only those axes corresponding to components with eigen values greater than 1.0 were extracted and plotted.

Phylogenetic analysis: Phylogenetic analysis was performed with PAUP ${ }^{*}$ Version $4.0 \mathrm{~b} 10$ for Macintosh (i book G4/Altivec). The two C. rosea specimens collected from Ginigathhena were used as the out group.

Heuristic searches of 1000 random unordered taxon addition replicates with equal weight criterion were executed with TBR (Tree Bisection and Reconstruction) branch swapping and MULtrees (Multiple Parsimonious trees) in effect, keeping only 10 trees for each replicate in order to reduce time spent in swapping on suboptimal trees. The resulting trees were then used as starting trees to find as many trees of maximum parsimony as possible. Branches were collapsed if minimum length is zero. Finally, a cladogram and a phylogram were obtained. Strict consensus trees were constructed from all the most parsimonious trees obtained from individual and combined searches. Consistency Index (CI) and Retention Index (RI) were calculated. Bootstrap analysis (100 replicates, full heuristic search using random addition sequence and TBR branch swapping) was applied to each matrix as an internal support. All clades discovered in at least $50 \%$ of these replicates are reported.

Preparation of key to the Sri Lankan Garcinia species: Although the genus has comprehensive keys based on flower and fruit characters, field identification is challenging as a result of the strict seasonality of flowering and fruiting of these species. Therefore, a dichotomous key was constructed using conspicuous vegetative morphological characters.

\section{RESULTS}

\section{Cluster analysis}

Two different dendograms were obtained from the cluster analysis using Unweighted Pair Group Method with Arithmetic Mean (UPGMA) and Neighbour Joining (NJ) methods.

Both the UPGMA and NJ analyses distinctly delimited the eight Sri Lankan Garcinia species used in the present study. The relationships shown by the species based on the overall similarity are similar with both UPGMA and NJ methods except for the variation in the placement of G. spicata. Therefore, only the UPGMA dendogram is illustrated in Figure 3. 


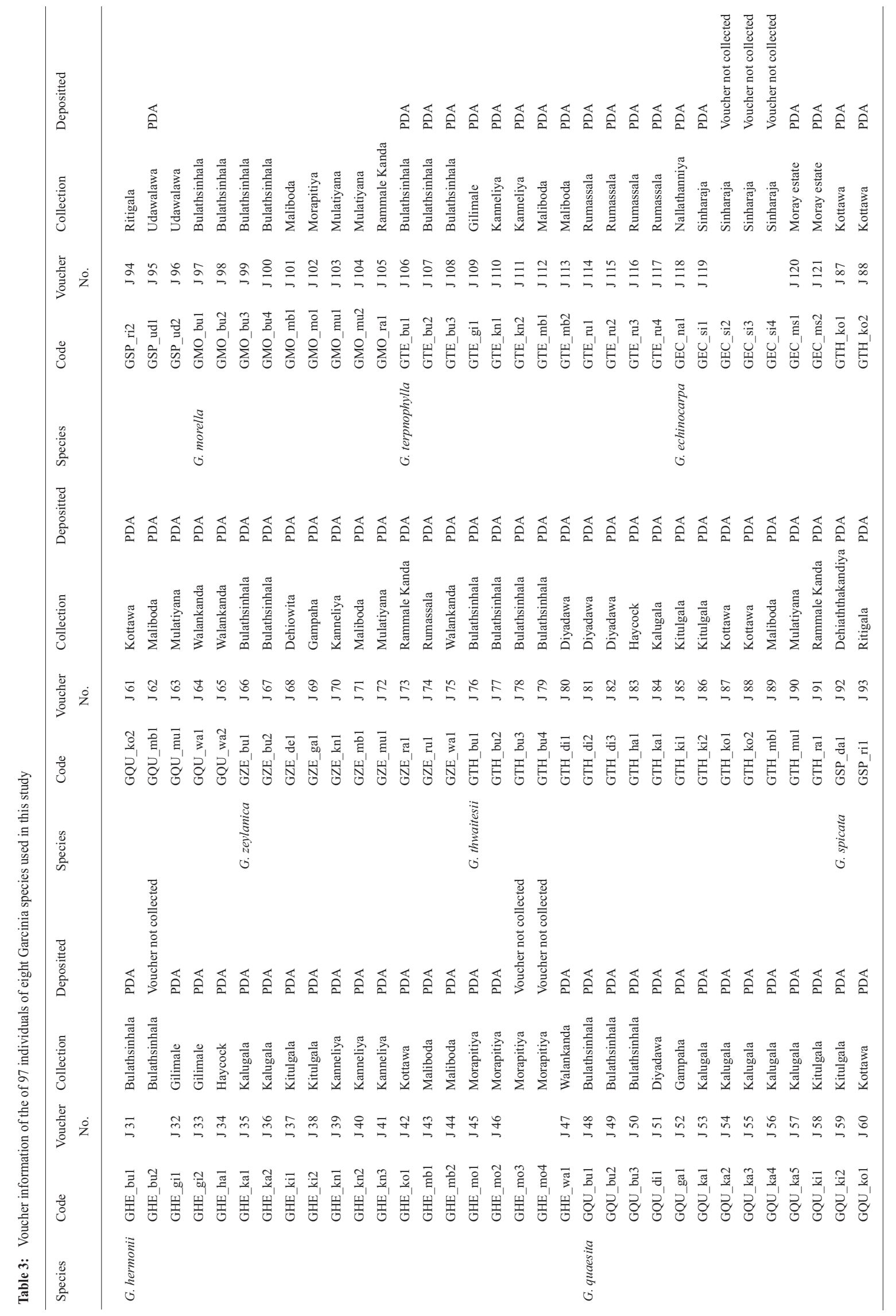


Sri Lankan Garcinia species cluster into two major groups in both analyses. One of these two major clusters includes G. hermonii, G. spicata, G. thwaitesii and $G$. echinocarpa (cluster 1) and the other group (cluster 2) includes G. quaesita, G. morella, G. zeylanica and $G$. terpnophylla.

Cluster 1 shows a further division into two subgroups. This division illustrates a slight variation in the two analyses due to the incongruence in the placement of G. spicata. The UPGMA analysis placed G. spicata in a common subgroup with $G$. hermonii, $G$. thwaitesii and $G$. echinocarpa from the second subgroup. On the contrary, the Neighbour Joining tree places G. spicata in the cluster in which G. thwaitesii and G. echinocarpa are included, while $G$. hermonii alone forms the other major subgroup.

Cluster 2 is divided into two subgroups (Figure 3). One subgroup includes only the individuals of $G$. terpnophylla. The other three species (G. morella, G. quaesita and G. zeylanica) of cluster 2 are comparatively similar in vegetative morphology, except for a few hardly identifiable vegetative morphological characters.

\section{Principal component analysis (PCA)}

Component loading of each species along the component axes are given in Table 5. Species such as G. spicata, G. hermonii. G. echinocarpa and G. thwaitesii indicated a considerable contribution to the first principal component axis and $G$. terpnophylla shows its wide contribution for the second component axis.

On the other hand, the individuals of $G$. morella were heavily loaded along the third component axis. The fourth and fifth components loaded with G. quaesita and $G$. zeylanica could be considered as negligible component axes with the loading of variables along these components being insignificant. The resulting scatter plots revealed that there is a more or less clear grouping pattern of specimens and thus those characters considered in the study are important in the delimitation of the Sri Lankan Garcinia species (Figure 4).

The Principal Component Analysis illustrates that the Sri Lankan indigenous species clearly circumscribe the species limits, with few exceptions. G. terpnophylla and $G$. hermonii which show a division among the individuals supported by leaf characteristics. G. spicata shows a close relationship with the $G$. hermonii group. G. echinocarpa placed in a distant cluster is characterized by morphological characters such as the red coloured petiole, stilt roots and convex lamina. Its distribution is confined to the lower montane and sub montane zones of Sri Lanka.

\section{Phylogenetic analysis}

A comprehensive analysis was carried out to generate a cladogram with the maximum parsimony method using C. rosea as the out group species. One out of the 1198 most parsimonious trees (phylogram) is illustrated in Figure 5.

The most parsimonious trees have a length of 165 steps, CI of 0.3515 and a RI of 0.9254 . The branch lengths are shown using tree number 1 of the 1198 trees (ACCTRAN optimization) (Figure 5).

The strict consensus tree of the 1198 most parsimonious trees of Sri Lankan Garcinia species is illustrated in Figure 6 including the clades with bootstrap support greater than 50. Monophyly of Sri Lankan Garcinia species is well supported (BP 100), and except for $G$. hermonii other Sri Lankan Garcinia species circumscribed into well-supported monophyletic clades.

Sri Lankan Garcinia species form two major clades. The first clade consists of G. hermonii, G. spicata, $G$. thwaitesii and $G$. echinocarpa and these species possess coriaceous leaves (clade 1). The second clade which includes G. quaesita, G. morella, G. zeylanica and G. terpnophylla (clade 2) has non-coriaceous leaves (Figures 5 and 6).

G. herinonii in clade 1 shows a highly unresolved relationship forming a polytomy. Although it shows an unresolved relationship in the strict consensus tree, the phylogram obtained from the maximum parsimony method shows that it forms a distinct clade with eight out of the forty seven distinct morphological characters and the individuals are differentiated into two major groups, which is also supported by the PCA. The other three species, namely G. spicata, G. thwaitesii and $G$. echinocarpa form strong monophyletic clade inferred by the strict consensus tree. G. spicata is sister to $G$. echinocarpa and forms a strong monophyletic clade with bootstrap support of 92 (Figures 5 and 6). These three species show a distinct clade from $G$. hermonii, with thirteen character diversions in the phylogram.

Compared to the species of clade 1, the species belonging to clade 2 form strong relationships. G. terpnophylla forms a lonely but strong monophyletic subclade with bootstrap support of 83. In addition, it is sister to the other major subclade of clade 2 which comprises G. quaesita, G. zeylanica and G. morella. 
The subclade consisting G. quaesita, G. zeylanica and $G$. morella is well supported with a bootstrap support of 91. The subclade containing these three species again forms a relationship dividing into two parts with bootstrap support of 71 and 79. G. quaesita and G. morella are included in the part with 71 percent bootstrap support, being sister to each other, they strongly circumscribe with 95 and 92 percent of bootstrap values accordingly (Figure 6).

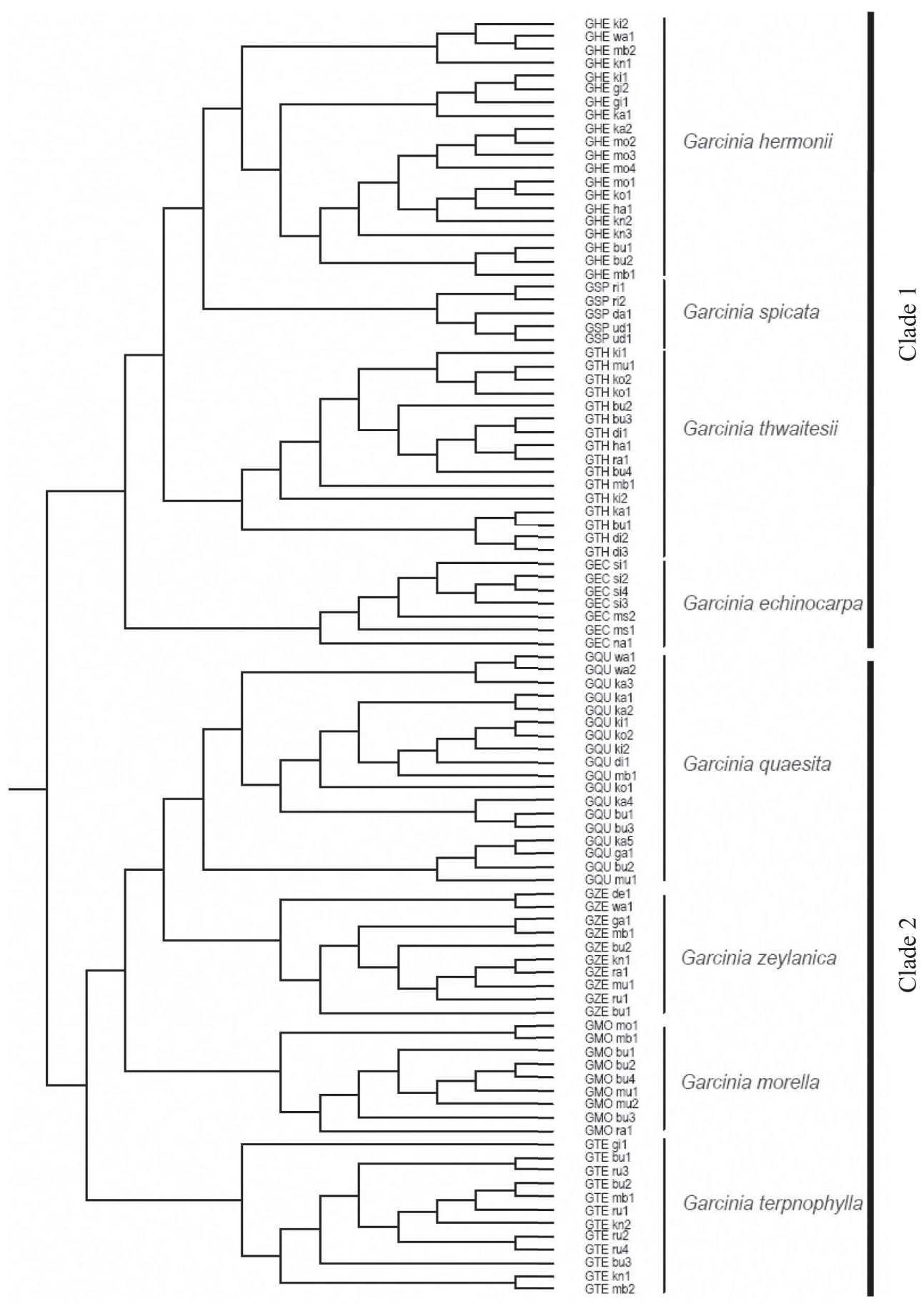

Figure 3: The UPGMA dendogram of eight indigenous Garcinia species in Sri Lanka inferred by forty seven vegetative morphological characters. Major clusters and representative species are marked. 
Table 4: The vegetative characters and character states used in the study

\begin{tabular}{|c|c|c|c|c|c|c|}
\hline \multirow[t]{2}{*}{ Code } & \multirow[t]{2}{*}{ Character } & \multicolumn{5}{|c|}{ Character states } \\
\hline & & 0 & 1 & 2 & 3 & 4 \\
\hline $\mathrm{C} 1$ & Leaf length (LL) & $0.0>\mathrm{LL}>12.0 \mathrm{~cm}$ & $12.0<\mathrm{LL}<=24.0 \mathrm{~cm}$ & & & \\
\hline $\mathrm{C} 2$ & Leaf width (LW) & $\mathrm{LW}<=5.0 \mathrm{~cm}$ & $\mathrm{LW}>5.0 \mathrm{~cm}$ & & & \\
\hline $\mathrm{C} 3$ & Petiole length (PL) & $\mathrm{PL}<2.0 \mathrm{~cm}$ & $P L>=2.0 \mathrm{~cm}$ & & & \\
\hline $\mathrm{C} 4$ & Petiole diameter (PD) & $\mathrm{PL}<0.2 \mathrm{~cm}$ & $\mathrm{PL}>=0.2 \mathrm{~cm}$ & & & \\
\hline $\mathrm{C} 5$ & Leaf: length/ width (Rl) & $\mathrm{Rl}>2.0$ & $\mathrm{Rl}<=2.0$ & & & \\
\hline C6 & Petiole: length/ width (Rp) & $\mathrm{Rp}<=8.0$ & $\mathrm{Rp}>8.0$ & & & \\
\hline $\mathrm{C} 7$ & Number of secondary veins (\#V) & $0<\# \mathrm{~V}<25$ & $25<\# \mathrm{~V}<50$ & $50<\# \mathrm{~V}<75$ & & \\
\hline $\mathrm{C} 8$ & Branchlet tip diametre (TD) & $\mathrm{TD}<0.3$ & $\mathrm{TD}>0.3$ & & & \\
\hline C9 & Groove length (GL) & $\mathrm{GL}<0.3$ & $\mathrm{GL}>0.3$ & & & \\
\hline $\mathrm{C} 10$ & Angle of leaf tip (T) & $\mathrm{T}<50$ & $\mathrm{~T}>50$ & & & \\
\hline $\mathrm{C} 11$ & Angle of leaf base (B) & $\mathrm{B}<100$ & $\mathrm{~B}>100$ & & & \\
\hline $\mathrm{C} 12$ & Leaf thickness (LT) & $\mathrm{LT}<0.3$ & $\mathrm{LT}>0.3$ & & & \\
\hline $\mathrm{C} 13$ & Angle in 1ry \& 2ry veins (V) & $0<\mathrm{V}<45$ & $45<\mathrm{V}<90$ & & & \\
\hline $\mathrm{C} 14$ & Bark colour & Rusty black & Smooth brown & & & \\
\hline $\mathrm{C} 15$ & Live bark colour & Off white & Beefy red & Brown & & \\
\hline $\mathrm{C} 16$ & Sap colour & Luminous Yellow & Brick red & White & Off white & \\
\hline $\mathrm{C} 17$ & branchlet TS shape & Cylindrical & Subcylindrical & Quadrangular & & \\
\hline $\mathrm{C} 18$ & Leaf texture - Fresh leaf & Coriaceous & Non coriaceous & & & \\
\hline $\mathrm{C} 19$ & Leaf texture - Dried leaf & Coriaceous & Non coriaceous & & & \\
\hline $\mathrm{C} 20$ & Leaf shape & Elliptic & Ovate $\square$ & Oblong & Obovate & Oval \\
\hline $\mathrm{C} 21$ & Leaf bent down at tip region & Yes & No & & & \\
\hline $\mathrm{C} 22$ & shape of leaf apex & Acute & Cuspidate & Obtuse & Emarginate & \\
\hline $\mathrm{C} 23$ & shape of the leaf base & Attenuate & Rounded & & & \\
\hline $\mathrm{C} 24$ & Colour of the young leaf & Redish brown & Light green & Dark green & & \\
\hline $\mathrm{C} 25$ & Colour of the young leaf margin & Redish brown & Green & & & \\
\hline $\mathrm{C} 26$ & Decurrent nature of leaf base & Present & Absent & & & \\
\hline $\mathrm{C} 27$ & Presence of a foveola & Present & Absent & & & \\
\hline $\mathrm{C} 28$ & Midrib nature/ upper surface & Flat & Raised & Impressed & & \\
\hline $\mathrm{C} 29$ & Midrib nature/ lower surface & Flat & Raised & Impressed & & \\
\hline $\mathrm{C} 30$ & Midrib nature at base & Flat & Raised & & & \\
\hline $\mathrm{C} 31$ & Colour of the midrib & Totally green & Reddish brown at base & & & \\
\hline $\mathrm{C} 32$ & Colour of the petiole & Totally green & Reddish brown & & & \\
\hline $\mathrm{C} 33$ & Colour of the young petiole & Totally green & Reddish brown & & & \\
\hline $\mathrm{C} 34$ & petiole nature & Stout & Slender & & & \\
\hline $\mathrm{C} 35$ & Groove in the branchlets & Present & Absent & & & \\
\hline $\mathrm{C} 36$ & Stilt roots & Present & Absent & & & \\
\hline $\mathrm{C} 37$ & Aerial roots & Present & Absent & & & \\
\hline $\mathrm{C} 38$ & Strangler roots & Present & Absent & & & \\
\hline $\mathrm{C} 39$ & Buttresses & Present & Absent & & & \\
\hline $\mathrm{C} 40$ & Secondary vein arrangement & Dense & Loose & & & \\
\hline $\mathrm{C} 41$ & Presence of inter marginal vein & Present & Absent & & & \\
\hline $\mathrm{C} 42$ & Pattern of tertiary veins & Reticulate & Parallel & & & \\
\hline $\mathrm{C} 43$ & Relationship of tertiary to mid vein & Parallel & Not parallel & & & \\
\hline $\mathrm{C} 44$ & Intermediate secondary vein nature & Reach margin & Not reach margin & & & \\
\hline $\mathrm{C} 45$ & Cup shape of the leaf & Present & Absent & & & \\
\hline $\mathrm{C} 46$ & Pubescence & Present & Absent & & & \\
\hline $\mathrm{C} 47$ & Mid vein invisible at the apex & Yes & No & & & \\
\hline
\end{tabular}


Table 5: Results of principal component analysis on forty seven vegetative morphological characters of ninety seven specimens of eight indigenous Garcinia species in Sri Lanka. Variables arranged in descending order according to loadings on first component. The heavily loaded components are shown in bold letters.

\begin{tabular}{|c|c|c|c|c|c|c|c|c|c|c|c|c|c|}
\hline \multirow[b]{2}{*}{ Species } & \multicolumn{6}{|c|}{ Axis (Component) } & \multicolumn{7}{|c|}{ Axis (Component) } \\
\hline & 1 & 2 & 3 & 4 & 5 & 6 & Species & 1 & 2 & 3 & 4 & 5 & 6 \\
\hline GSP_ril & 5.4042 & -0.5489 & -1.2430 & 1.0358 & -0.2955 & 2.6689 & GTE_kn1 & 0.6427 & 4.1213 & -2.5492 & 3.2527 & 0.0199 & -0.8107 \\
\hline GSP_ri2 & 5.4042 & -0.5489 & -1.2430 & 1.0358 & -0.2955 & 2.6689 & GTE_bu1 & 0.1941 & 4.2190 & -2.6950 & 3.3567 & 0.2028 & -0.7877 \\
\hline GEC_kn1 & 4.8677 & 0.3878 & -1.2702 & -2.4567 & 1.4041 & 0.5119 & GTE_bu2 & 0.1941 & 4.2190 & -2.6950 & 3.3567 & 0.2028 & -0.7877 \\
\hline GSP_da1 & 4.8649 & -0.5218 & -1.2664 & 1.4116 & -0.1121 & 2.6734 & GTE_bu3 & 0.1941 & 4.2190 & -2.6950 & 3.3567 & 0.2028 & -0.7877 \\
\hline GHE_mb2 & 4.5632 & 0.0823 & 0.4430 & -3.2360 & 1.7031 & -0.4479 & GTE_ru1 & 0.1941 & 4.2190 & -2.6950 & 3.3567 & 0.2028 & -0.7877 \\
\hline GHE_wa1 & 4.5552 & 0.5512 & -0.1140 & -3.5840 & 0.8216 & 0.0954 & GTE_ru2 & 0.1941 & 4.2190 & -2.6950 & 3.3567 & 0.2028 & -0.7877 \\
\hline GEC_ms1 & 4.5418 & -5.7815 & -4.1061 & 0.9163 & 1.7329 & -0.0201 & GTE_kn2 & 0.1941 & 4.2190 & -2.6950 & 3.3567 & 0.2028 & -0.7877 \\
\hline GSP_ud1 & 4.4820 & -0.3632 & -0.8313 & 1.6264 & -0.3932 & 2.6215 & GTE_ru3 & 0.1941 & 4.2190 & -2.6950 & 3.3567 & 0.2028 & -0.7877 \\
\hline GSP_ud1 & 4.4820 & -0.3632 & -0.8313 & 1.6264 & -0.3932 & 2.6215 & GTE_ru4 & 0.1941 & 4.2190 & -2.6950 & 3.3567 & 0.2028 & -0.7877 \\
\hline GEC_si1 & 4.4700 & -4.7154 & -4.6487 & -0.5567 & 1.2928 & -0.2589 & GTE_mb1 & 0.1941 & 4.2190 & -2.6950 & 3.3567 & 0.2028 & -0.7877 \\
\hline GHE_ki2 & 4.2315 & 0.2338 & -0.1538 & -3.2712 & 1.4827 & 0.0794 & GTE_gil & -0.6117 & 1.6503 & -1.7167 & 2.1176 & -1.6946 & -1.4017 \\
\hline GHE_ka2 & 4.1870 & 1.9372 & & & & & GMO_mb1 & -3.8295 & -0.7338 & & 1.5391 & 3.3454 & -1.0862 \\
\hline GHE_mo1 & 4.1870 & 1.9372 & 0.8886 & -3.0228 & -0.2178 & -0.5107 & GMO_ral & -3.8934 & -0.7703 & 2.5691 & 0.8208 & 3.9430 & -1.0191 \\
\hline GHE_mo2 & & 1.9372 & & & & & & & & & 5239 & 2.5370 & -1.2247 \\
\hline GHE_mo3 & 4.1870 & 1.9372 & 0.8886 & -3.0228 & -0.2178 & -0.5107 & GMO_bu1 & -3.9254 & -0.7886 & 2.7968 & 0.4617 & 4.2417 & -0.9856 \\
\hline GHE_mo4 & 4.1870 & 1.9372 & 0.8886 & -3.0228 & -0.2178 & -0.5107 & GMO_bu2 & -3.9254 & -0.7886 & 2.7968 & 0.4617 & 4.2417 & -0.9856 \\
\hline GHE_ha1 & 4.1870 & 1.9372 & 0.8886 & -3.0228 & -0.2178 & -0.5107 & GMO_bu4 & -3.9254 & -0.7886 & 2.7968 & 0.4617 & 4.2417 & -0.9856 \\
\hline GHE_kn2 & 4.1870 & 1.9372 & 0.8886 & -3.0228 & -0.2178 & -0.5107 & GMO_mul & -3.9254 & -0.7886 & 2.7968 & 0.4617 & 4.2417 & -0.9856 \\
\hline GHE_ko1 & 4.1870 & 1.9372 & 0.8886 & -3.0228 & -0.2178 & -0.5107 & GMO_mu2 & -3.9254 & -0.7886 & & 0.4617 & 4.2417 & -0.9856 \\
\hline GEC_ms2 & 4.1189 & -5.2889 & -4.3389 & 0.2572 & 2.2772 & -0.6905 & GZE_ga1 & -3.9984 & 1.4534 & 0.1245 & -1.0856 & 0.5904 & 2.8129 \\
\hline GEC_si2 & & & & & & & & & & & & & 2.8129 \\
\hline GEC_si3 & 4.1109 & -4.8199 & -4.8960 & -0.0909 & 1.3957 & -0.1473 & GMO_bu3 & -4.1536 & -0.9147 & 2.9983 & 0.4817 & 4.2685 & -0.2735 \\
\hline GEC_si4 & & & & & 1.3957 & & GQU_bu2 & -4.1565 & & -2.2998 & -0.2857 & -2.3554 & 1.1061 \\
\hline GHE_mb1 & 3.9398 & 1.5740 & 1.7358 & -2.5316 & 0.4763 & -1.0886 & GZE_de1 & -4.2948 & 1.4136 & 0.0068 & -1.5262 & -0.0399 & 2.3083 \\
\hline GHE_bu1 & 3.9317 & 2.0429 & 1.1787 & -2.8797 & -0.4053 & -0.5454 & GZE_wa1 & -4.2948 & 1.4136 & .0068 & -1.5262 & -0.0399 & 2.3083 \\
\hline GHE_bu2 & 3.9317 & 2.0429 & & -2.8797 & -0.4053 & & GQU_ga1 & -4.3631 & -1.4413 & -1.8390 & -0.5332 & -2.1947 & -0.3077 \\
\hline GHE_ka1 & 3.8634 & 1.6198 & 0.8488 & -2.7101 & 0.4433 & -0.5267 & GZE_bu2 & -4.3734 & 1.7000 & -0.0491 & -0.8704 & 0.8671 & 2.4536 \\
\hline GHE_kn1 & 3.8279 & 1.8326 & 0.6413 & -2.5570 & -0.1149 & & GZE_kn1 & & & & -0.8704 & 0.8671 & 2.4536 \\
\hline GHE_kil & 3.7907 & 2.0681 & 1.0679 & -2.7253 & -0.3652 & -0.6652 & GZE_mu1 & -4.3734 & 1.7000 & -0.0491 & -0.8704 & 0.8671 & 2.4536 \\
\hline GHE_gi2 & & & & & & & & & & & & & .4536 \\
\hline GEC_na1 & 3.4386 & -5.4592 & -4.4255 & 0.3250 & 2.5366 & -0.3871 & GZE_ru1 & -4.3734 & 1.7000 & -0.0491 & -0.8704 & 0.8671 & .4536 \\
\hline GHE_gil & & 1.9237 & 0.7030 & -2.7000 & -0.8926 & -1.0582 & GQU_ka3 & -4.4050 & -1.6304 & -1.1144 & -1.0579 & -1.6100 & 0.2423 \\
\hline GTH_bul & 2.9798 & -2.1978 & 2.5935 & 1.8043 & -1.2020 & 0.3837 & GQU_wal & -4.4704 & -2.6689 & -1.9570 & -1.1874 & -1.0711 & -0.1048 \\
\hline GTH_mb1 & 2.6889 & -1.7208 & 2.7636 & 2.1445 & -1.4035 & -0.1512 & GQU_ka5 & -4.4908 & -1.3884 & -1.6940 & -0.4616 & -2.2884 & -0.3250 \\
\hline GTH_bu4 & 2.6721 & -1.7316 & 3.4852 & 1.4842 & -1.4521 & & GZE_bu1 & -4.6016 & 1.5739 & 0.1524 & -0.8504 & 0.8939 & 3.1657 \\
\hline GTH_bu3 & 2.2757 & -1.6007 & 3.6646 & 1.7818 & -1.5995 & -0.2629 & GQU_wa2 & -4.7350 & -2.6940 & -1.8898 & -1.2844 & -0.8005 & 0.1422 \\
\hline GTH_dil & & & & & & & GQU_mu1 & & & & -0.3281 & -0.9327 & -0.2988 \\
\hline GTH_bu2 & 2.0475 & -1.7268 & 3.8660 & 1.8018 & -1.5727 & 0.4492 & GQU_bu3 & -5.1281 & 0.0559 & 0.2132 & -0.7352 & -0.8991 & -0.0957 \\
\hline GTH_mu1 & 1.9985 & -1.4060 & 3.0911 & 2.8538 & -1.7311 & 0.0498 & GQU_ko1 & -5.2013 & -1.9533 & -1.9051 & -1.3850 & -2.2406 & -0.8325 \\
\hline GTH_ko1 & 1.9985 & -1.4060 & 3.0911 & 2.8538 & -1.7311 & 0.0498 & GQU_ka1 & -5.2506 & -0.8159 & -0.3007 & -1.6114 & -2.1539 & -0.7066 \\
\hline GTH_ko2 & 1.9985 & -1.4060 & 3.0911 & 2.8538 & -1.7311 & 0.0498 & GQU_ka4 & -5.3291 & -0.5295 & -0.3566 & -0.9555 & -1.2469 & -0.5613 \\
\hline GTH_ka1 & 1.9735 & -1.9281 & 3.0526 & 2.0941 & -0.9322 & 0.3164 & GQU_bu1 & -5.3563 & -0.0703 & 0.4146 & -0.7152 & -0.8723 & 0.6164 \\
\hline GTH_ki2 & 1.9224 & -1.1662 & 2.2857 & 3.5464 & -1.3597 & 0.0596 & GQU_ka2 & -5.6256 & -0.5692 & -0.4743 & -1.3961 & -1.8772 & -1.0659 \\
\hline GTH_ha1 & 1.9166 & 1.7052 & 3.4173 & 2.2476 & -1.4966 & -0.1512 & GQU_mb1 & -5.6361 & -1.2123 & -1.2428 & -1.6124 & -2.0531 & -1.5342 \\
\hline GTH_ra1 & 1.9166 & -1.7052 & 3.4173 & 2.2476 & -1.4966 & -0.1512 & GQU_ki1 & -5.7638 & -1.1594 & -1.0977 & -1.5408 & -2.1468 & -1.5515 \\
\hline GTH_kil & 1.5549 & -1.3982 & 3.3678 & 2.5059 & -1.2274 & -0.2358 & GQU_ki2 & -5.7638 & -1.1594 & -1.0977 & -1.5408 & -2.1468 & -1.5515 \\
\hline GTH_di2 & 1.2585 & -2.2746 & 3.1948 & 2.2012 & -1.0894 & 0.5499 & GQU_di1 & -5.7638 & -1.1594 & -1.0977 & -1.5408 & -2.1468 & -1.5515 \\
\hline GTH_di3 & 1.2585 & -2.2746 & 3.1948 & 2.2012 & -1.0894 & 0.5499 & GQU_ko2 & -5.7638 & -1.1594 & -1.0977 & -1.5408 & -2.1468 & -1.5515 \\
\hline GTE_mb2 & 1.0391 & 3.9904 & -2.7286 & 2.9552 & 0.1673 & -0.6562 & & & & & & & \\
\hline
\end{tabular}




\section{Dichotomous key to the Sri Lankan Garcinia species}

The dichotomous key prepared using distinct morphological characters that can be easily identified in the field is illustrated in Figure 7.

The initial categorization of the species is easy with the character of coriaceousness or non-coriaceousness of leaf texture. G. echinocarpa, G. hermonii, G. spicata and $G$. thwaitesii are included in the category of the species with coriaceous leaves. G. echinocarpa and G. hermonii can be separated from the rest of the species of this group based on the arrangement of the secondary veins. Both these species have a densely arranged $(0.2-0.8 \mathrm{~cm}$ between two secondary veins) secondary venation and they can be distinctly identified by their petiole colour. The other two species G. spicata and G. thwaitesii possess loosely arranged secondary veins $(>0.8 \mathrm{~cm}$ between two secondary veins) and they are characterized by the of the leaf tip nature (Figure 7).

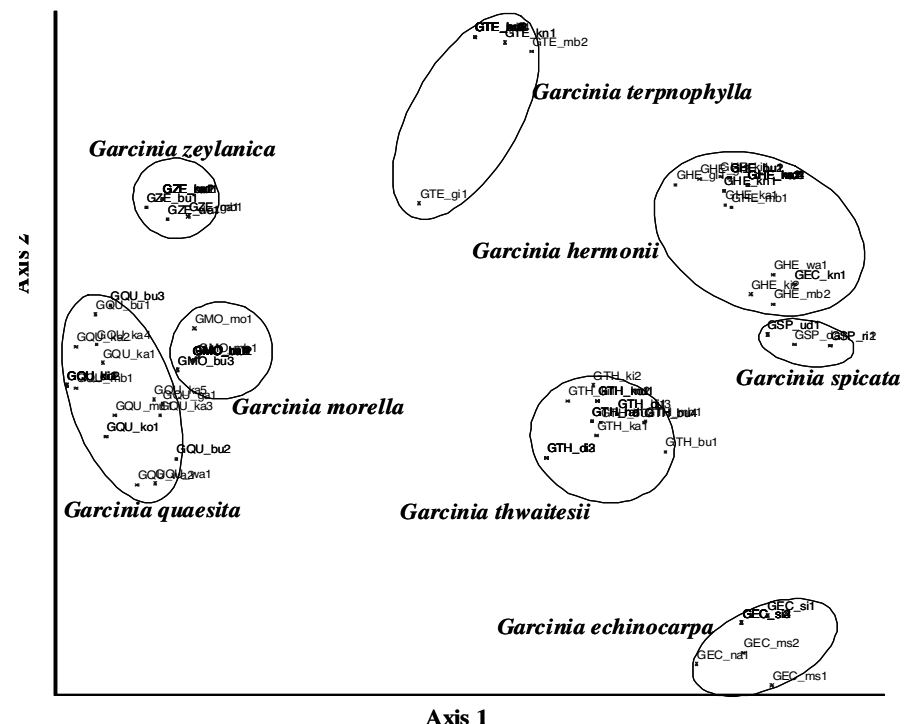

a)

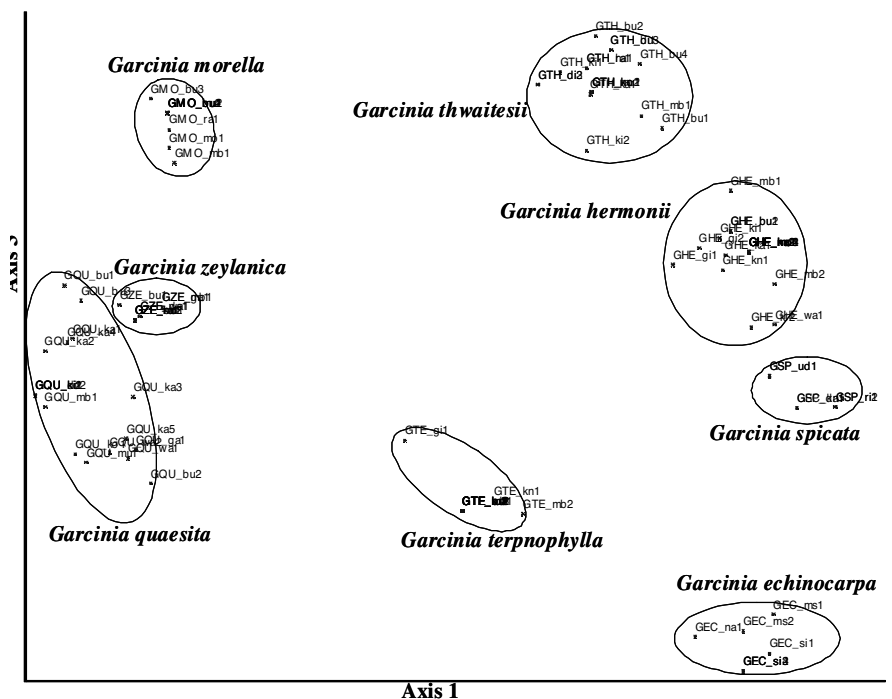

b)

Figure 4: a) PCA scatter diagram produced by plotting the first PC against the second for vegetative morphological characters of the Sri Lankan Garcinia species; b) PCA scatter diagram produced by plotting the first PC against the third for vegetative morphological characters of the Sri Lankan Garcinia species;

species codes are as follows. GZE- G. zeylanica, GQU- G. quaesita, GMO- G. morella, GTEG. terpnophylla, GTH- G. thwaitesii, GHE- G. hermonii, GEC- G. echinocarpa GSP- G. spicata 
Garcinia morella, G. quaesita, G. zeylanica and $G$. terpnophylla possess non-coriaceous leaves. $G$. terpnophylla can be distinctly identified among the species of this group by the presence of an intermarginal vein. The other three species G. morella, G. quaesita and $G$. zeylanica are very similar to each other. G. morella and $G$. zeylanica have brilliant yellow coloured latex, which separates them from G. quaesita. G. morella can be differentiated by the presence of foveola in the leaf petiole. In addition it possesses very thick leaves and reddish coloured juvenile leaves. On the other hand $G$. zeylanica is characterized by its blood red coloured live bark. G. quaesita possesses a reddish brown coloured petiole and can be easily characterized by the orangish yellow (brick red) coloured latex (Figure 8).

\section{DISCUSSION}

The phylogeny of genus Garcinia is researched extensively all over the world, due to the paraphyletic nature of the genus according to the present circumscription. However the present study reveals that the Sri Lankan Garcinia species form a strong monophyletic clade. The species circumscriptions are also supported by a number of distinct morphological characters.

When the results of the simailarity methods are compared, Sri Lankan Garcinia species cluster into two major groups in both the NJ and UPGMA analyses. This separation is inferred by the leaf texture and the leaf size of the species. The major cluster which includes G. hermonii, G. spicata, G. thwaitesii and G. echinocarpa have coriaceous leaves (cluster 1), while the other group has non-coriaceous small leaves compared to the species of cluster 1 (Figure 3 ).

As the results illustrate the species in cluster 1 show a further division into two subgroups (Figure 3). The similarity relationship inferred by the analyses is robustly supported by many morphological features including leaf size, leaf shape, leaf tip and leaf base characteristics as well as the entire venation pattern.

Cluster 2 is divided into two subgroups (Figure 3). One major group includes only the individuals of $G$. terpnophylla. Although $G$. terpnophylla and the other species in cluster 2 are very similar in leaf characters such as the leaf size and texture, they are dissimilar from the related species in other major morphological characters showing more similarity to the species in cluster 1 such as white coloured sap, densely arranged secondary veins, which are nearly at right angles to the midvein, and oblong leaf shape.
G. terpnophylla not only possesses features common to the species of cluster 1 but is also characterized by distinct morphological characters such as presence of an intermarginal vein and a canopy tree with buttresses. These characters may have given $G$. terpnophylla a unique position in the UPGMA and analyses.

Even though $G$. terpnophylla has non-coriaceous leaf texture in common with the species in cluster 2, it has varying levels of thickness (coriaceous nature). One specimen collected from Gilimale (GTE gil) is highly coriaceous similar to the species in cluster 1 and the specimens collected from Maliboda trail to the Peak Wilderness Sanctuary (GTE mb2) and Kanneliya Forest Reserve (GTE knl) are similar to species of cluster 1 in leaf length. Their leaves have intermediate leaf thickness compared to the related species of the same cluster and those of cluster 1 (Figure 3). However, the other common characters among the individuals of $G$. terpnophylla place them in a single major group of cluster 2 (Figure 3 ).

The other three species of cluster 2 are similar in vegetative morphology, except for a few specimens with hardly identifiable vegetative morphological characters. Trimen $1893^{4}$ delimited these three species into two species; G. morella and G. cambogia. Both G. quaesita and $G$. zeylanica were included in $G$. cambogia, and $G$. zeylanica was considered as one variety ( $G$. cambogia var. papilla).

A similar relationship was observed during the current study. These three species form one subgroup of cluster 2. G. quaesita and G. zelanica show a very close relationship. The red coloured young leaf and the presence of a foveola in the petiole are characteristic features of G. morella. G. morella has thicker leaves than other two species. These characters may cause G. morella to be separated from the other two species.

Other than these unique characters, G. morella shares some characteristics in common with G. quaesita and $G$. zeylanica of the same subgroup. Both G. zeylanica and $G$. morella possess bright yellow coloured latex, while $G$. quaesita has bright orange coloured latex. The colour of the live bark of G. morella and G. quaesita is light brown and G. zeylanica has a blood red coloured live bark. Almost all the leaf lamina characteristics of the three species are similar.

The phylogenetic analysis shows an unresolved polytomy in $G$. hermonii. The vegetative morphology points to the presence of two types of $G$. hermonii in the field. It is interesting to note that both types coexist in the same ecological niche. Therefore, this morphological variation is not imposed by environmental factors. The 


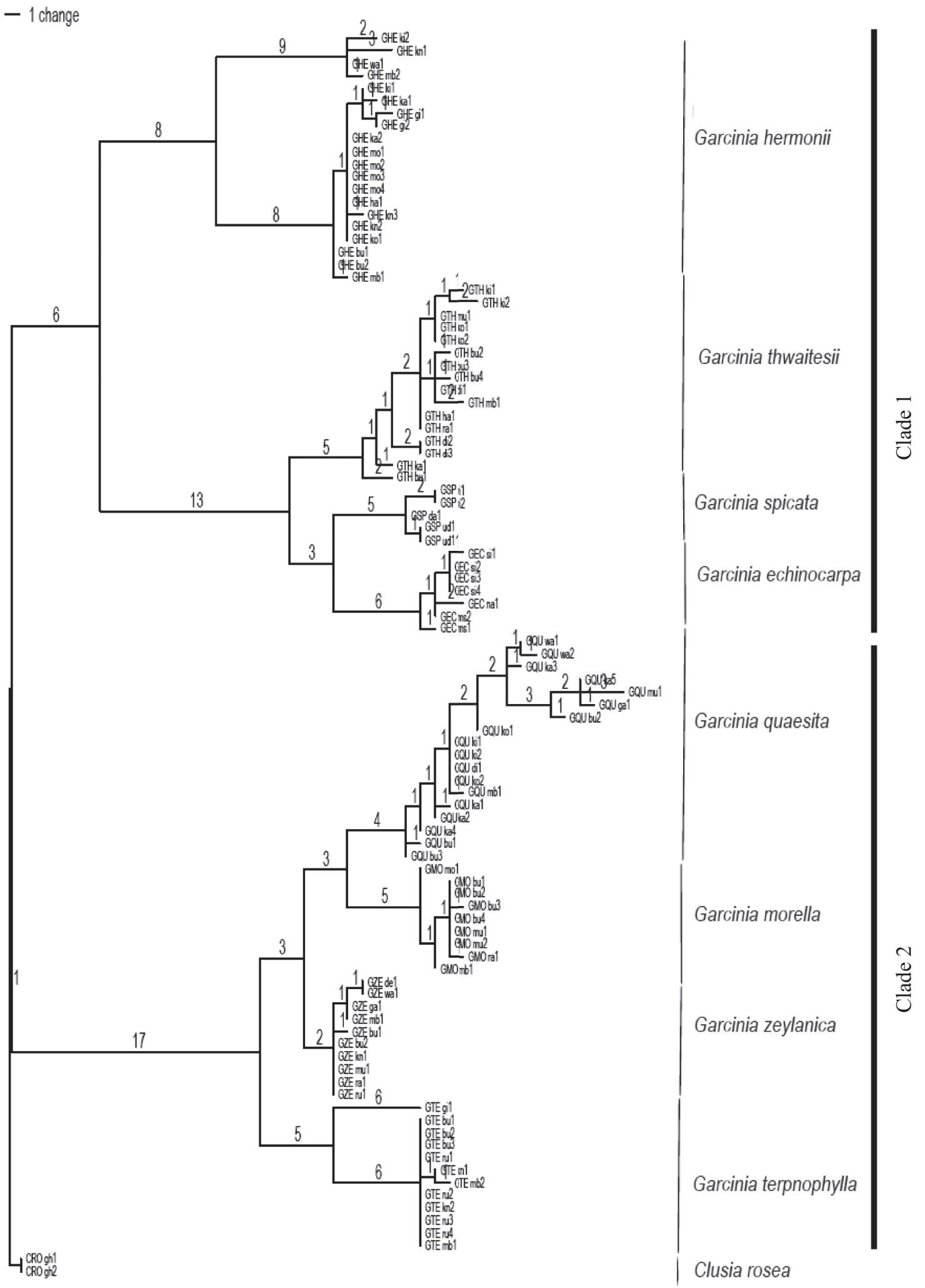

Figure 5: The phylogram obtained from the phylogenetic analysis of Sri Lankan Garcinia species using PAUP* version 4.0 b10 for Macintosh (i book G4/ Altivec) using 97 ingroup and 2 outgroup taxa inferred by forty seven vegetative morphological characters. The branch lengths are shown using tree number 1 of 1198 trees (ACCTRAN optimization). 


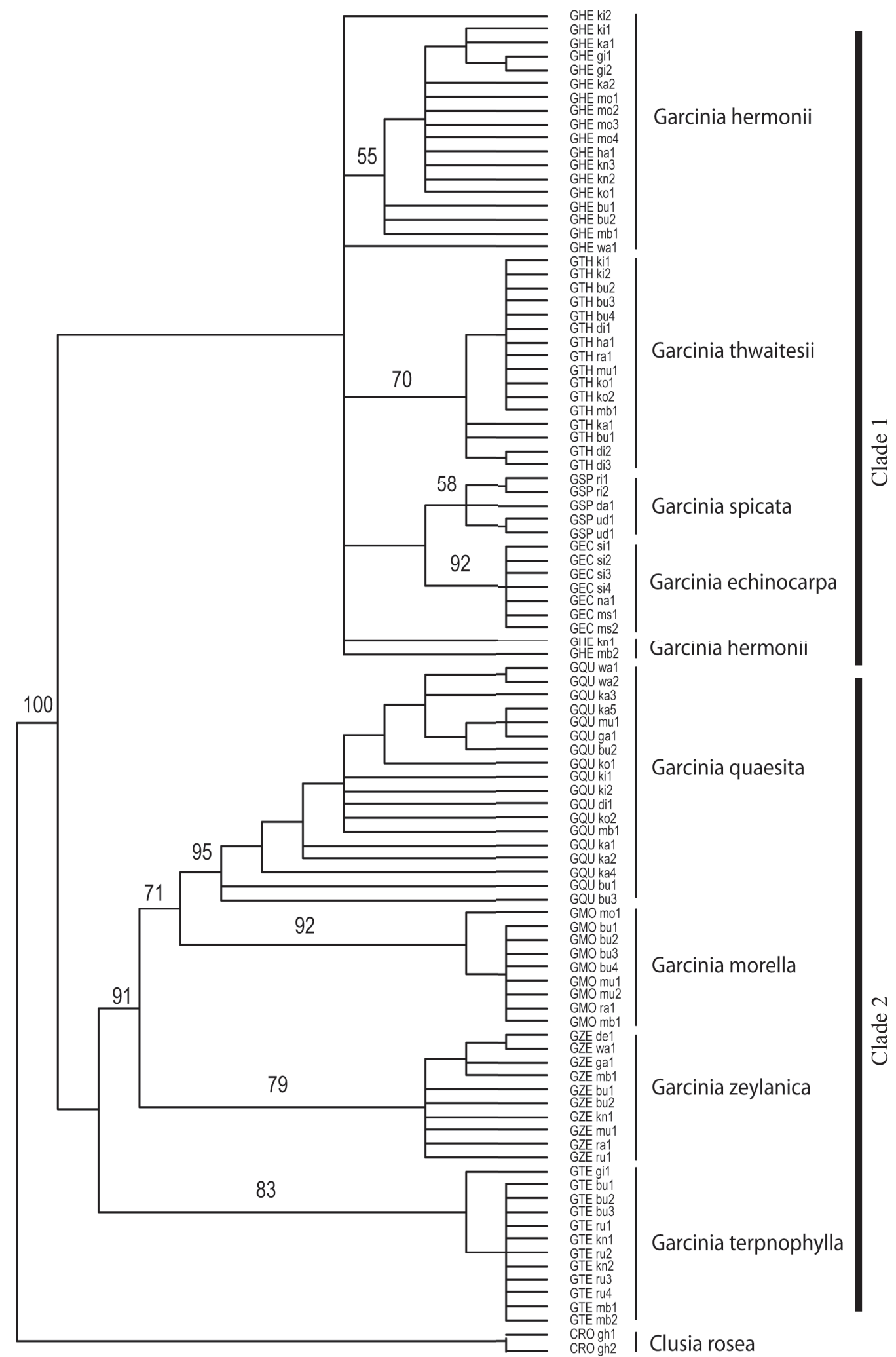

Figure 6: The strict consensious tree of the 1198 most parsimonious trees of Sri Lankan Garcinia species obtained from the phylogenetic analysis using 97 ingroup and 2 outgroup taxa inferred by forty seven vegetative morphological characters. The most parsimonious trees have a length of 165 steps, CI of 0.3515 and a RI of 0.9254 . The clades with bootstrap support greater than 50 are also included 


\section{KEY TO THE SRI LANKAN GARCINIA SPECIES (LEAF ARCHITECTURE)}

1. Coriaceous leaves

2. Leaves with densely arranged veins
4. Petiole reddish brown
G. echinocarpa
4. Petiole green
G. hermonii

2. Leaves with loosely arranged veins

5. Leaves with emarginated leaf tip

G. spicata

5. Leaves with acuminate leaf tip

G. thwaitesii

1. Non- coriaceous leaves

6. Leaves without intermarginal vein

7. Petiole with foveola G. morella

7. Petiole without foveola

8. Basal region of mid vein red coloured .............G. quaesita

8. Basal region of mid vein green coloured...........G. zeylanica

6. Leaves with strong intermarginal vein

G. terpnophylla

Figure 7: The dichotomous key prepared for the Garcinia species in Sri Lanka using leaf characteristics

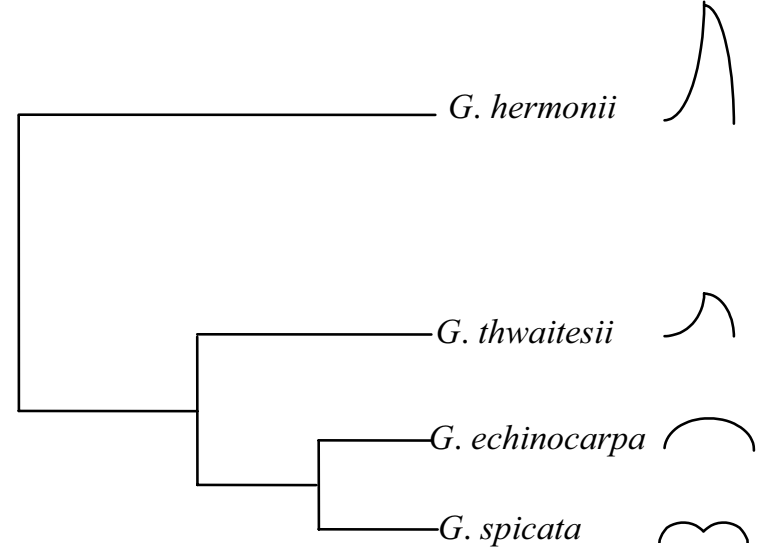

(a)

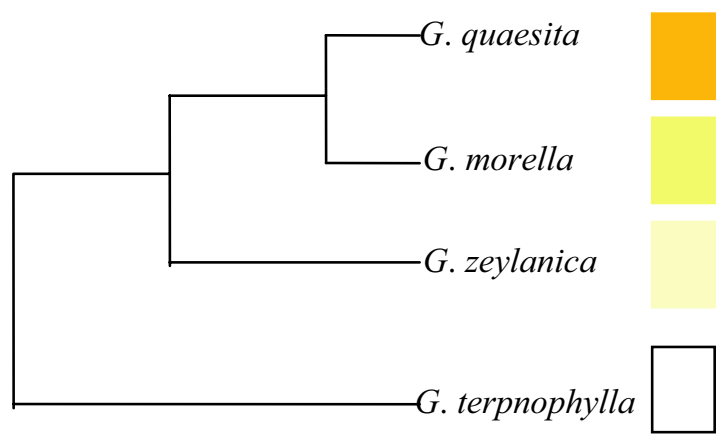

(b)

Figure 8: a) The leaf tip shapes of G. hermonii, G. thwaitesii, G. echinocarpa and G. spicata and their relationship appeared in the phylogenetic analysis. b) The latex colour variation in G. quaesita, G. morella, G. zeylanica and G. terpnophylla.

individuals with the similar vegetative morphology form a monophyletic clade in the strict consensus tree, while the positions of the individuals that diverged from the common situation are still unresolved. The PCA also showed such a division within the species. This suggests the presence of two distinct varieties of G. hermonii. The divergence could have occurred in the near past and the varietal characters are not strong enough to consider them as one clade.

The two Indo-Sri Lankan species G. spicata and G. echinocarpa show a close affinity to each other, while forming a monophyletic clade with endemic G. thwaitesii and G. hermonii. This may be an indication of the evolution of an endemic species. The relationships of these species are illustrated in relation to the nature 
of their leaf tips in Figure 8 a. Except for G. terpnophylla, the other species of clade 2 (Figure 5) show affinities with each other. G. quaesita, G. morella and G. zeylanica are very difficult to distinguish in the field without flowering specimens. However, the varying colours of their latex can be used in field identification (Figure $8 \mathrm{~b}$ ).

Individuals of $G$. quaesita are highly variable in vegetative morphology. Polymorphism in leaf shape plays a major role in variability within the species.

Kostermans $^{3}$ identified two distinct varieties of G. terpnophylla; var. acuminata found in the lowland wet zone and var. terpnophylla found in the montane zone. The montane variety has not been observed in the wild for nearly a century and is not sampled in the present study. All G. terpnophylla specimens in the present study were collected from the lowland wet zone. A withinspecies divergence is observed in G. terpnophylla like in G. hermonii.

The vegetative anatomical study ${ }^{11}$ of the genus Garcinia has also resulted in a similar relationship to that from clustering methods (Figure 5). The indigenous Garcinia species form two major clusters as evidenced from anatomical studies. The two clusters are composed of the same species as in the present study. However, the placement of G. morella in the preceding anatomical study shows a wide deviation and is grouped with the cluster 1 species.

The same anatomical study illustrates that $G$. hermonii forms one distinct cluster as inferred by the NJ tree. The other three species (G. thwaitesii, G. spicata and $G$. echinocarpa) form another cluster together with G. morella. The other major cluster includes G. quaesita, $G$. zeylanica and $G$. terpnophylla, and $G$. terpnophylla forms one subgroup with a close relationship between G. quaesita and G. zeylanica as in the present study.

\section{Conservation status of Sri Lankan Garcinia species}

The history of the field of taxonomy has shown that poorly resolved taxonomies have a negative impact on conservation assessment and lack of systematic knowledge of threatened taxa prevents effective conservation $^{11}$. Thus, systematic studies impose an enormous influence on conservation programmes.

Comprehensive revision on the conservation status of the Garcinia species appears to be vital. Garcinia species have not been assessed in detail for their distribution and conservation since the National Conservation Review $(\mathrm{NCR})^{12}$. The $\mathrm{NCR}^{12}$ was done as a rapid biodiversity survey to identify the localities with high biodiversity and to use in conservation strategies, and did not focus on the species composition due to several limitations.

Observations made during the current study revealed that the Garcinia species were absent even from the recorded NCR locations, while some locations recorded higher Garcinia species richness than was recorded in the NCR database.

Most of the herbarium specimens of lowland wet zone Garcinia species deposited in the National Herbarium have been collected from Morapitiya. During the current study, only a few individuals of three Garcinia species were sampled from Kalugala and Morapitiya areas, which are now highly disturbed due to encroachments. Our observations reveal that the diversity of Garcinia species has considerabley declined in these locations.

The national IUCN red data list has not considered Garcinia species for the latest revision ${ }^{7}$ mainly due to financial, time and resource constraints and the poor knowledge on the distribution of the species in Sri Lanka. Even where information is available the data is limited. Inadequate herbarium collections of plant species were a constraint to confirmation of the occurrence of species. Thus, the conservation status of these species is also uncertain.

The observations made during the present study revealed that $G$. terpnophylla is a highly threatened species in Sri Lanka and one of the varieties has not been recorded in the wild for nearly a century while the lowland wet zone variety is confined to small patches in the wet zone.

Wathurana, a fresh water swamp forest in Bulathsinhala, which is privately owned and comprises about 12 ha in land area, recorded the highest diversity of Garcinia species. All possible wet lowland species were sampled from the site and the species showed an even distribution. The individuals possess adventitious roots regardless of the species which may be an adaptation to the water logged, swampy environment. The Peak Wilderness Sanctuary is another location that recorded high species diversity of Garcinia. Being a large area and showing a wide variation in environmental, ecological and geographical factors, it recorded seven out of eight indigenous Garcinia species (explicitly G. spicata, which is the dry zone species).

\section{CONCLUSION}

Vegetative morphology can be successfully used to resolve species circumscriptions and identification 
of Sri Lankan Garcinia species. The present study reveals that Sri Lankan Garcinia forms two major groups within the genus; species with coriaceous leaves and species with non-coriaceous leaves.

The species can be distinctly identified by certain vegetative morphological characters. G. hermonii and $G$. echinocarpa have densely arranged secondary veins and the two species can be differentiated by the colour of the petiole and the shape of the leaf tip. G. spicata and $G$. thwaitesii can be easily distinguished from the venation characteristics. The veins of $G$. thwaitesii can be felt by hand.

G. quaesita, G. zeylanica and G. morella are very similar in vegetative morphology, and are commonly known as Goraka. The sap colour of G. quaesita trees is the best vegetative character for identifying them in the field. G. morella and G. zeylanica can be distinguished by the colour of live bark. G. zeylanica possess a dark reddish brown coloured live bark. G. terpnophylla have the unique character of an intermarginal vein and they are canopy trees of lowland wet evergreen forests. The mature individuals possess buttresses.

The study has revealed that Garcinia species diversity is declining in certain areas. Therefore, accurate and broad systematic studies of the genus will be an asset for the conservation perspectives of these species in Sri Lanka.

The genus Garcinia of order Malpighiales is one of the taxa with poorly resolved phylogenetic relationships. The molecular markers for the genus are now being developed, and those markers can be used to carry out DNA based studies for the Sri Lankan Garcinia species.

The results of the current study are congruent with those of the previous study which was based on vegetative anatomy ${ }^{9}$. Therefore combined multidisciplinary analysis of anatomy, vegetative and reproductive morphology as well as chemotaxonomy in necessary to study the more robust phylogeny of this group which could be used for studies of phytogeography and evolutionary radiation of the species.

\section{Acknowledgement}

Authors wish to thank Mr. T. N. Pieris for his guidance and support during the field work, the Forest Department of Sri Lanka for granting permission to carryout this study and to the curator and the staff of the National Herbarium, Peradeniya for providing permission to use the herbarium and the necessary assistance.

\section{References}

1. Angiosperm phylogeny. http//www.mobot.org/MOBOT/ research/APweb. Accessed on 21 April 2008.

2. Gustafsson M.H.G. \& Bittrich V. \& Stevens P.F. (2002). Phylogeny of Clusiaceae based on rbcl sequences. International Journal of Plant Sciences 163(6):10451054.

3. Kostermans A.J.G.H. (1980). In: A Revised Handbook to the Flora of Ceylon. vol 1 (Eds. Dassanayake M.D. \& Fosberg F.R.) pp. 72-89. Amerind Publishing Company (Pvt) Ltd, New Delhi 1:72-89.

4. Trimen H. (1893). A Handbook to the Flora of Ceylon, iii, pp..xvi+327. Bishen Singh Mahendrapal Singh, New Connaught Place, Dehra Dun, India.

5. Alston A.G.H. (1931). Supplement to Trimen's Handbook to the Flora of Ceylon, Part VI, p. 101. Dalau \& Co. Ltd., London.

6. International Union for conservation of Nature, Sri Lanka and the Ministry of Environment and Natural Resources (2007). The 2007. Red List of Threatened Fauna and Flora of Sri Lanka, Colombo.

7. Ashton M.S., Gunatilleke C.V.S., Singhakumara B.M.P. \& Gunatilleke I.A.U.N. (2001). Restoration pathway for main forests in South West Sri Lanka: a review of concepts and models. Forest Ecology and Management 154(3): 409-430.

8. Chomnawang M.T., Surassmo S., Nukoolkarn V.S. \& Gritsanapan W. (2005). Antimicrobial effects of Thai medicinal plants against acne-inducing bacteria. Journal of Ethnopharmacology 101(1-3): 330-333.

9. Jiang D.J. (2004). Pharmacological effects of xanthones as cardiovascular protective agents. Cardiovascular Drug Reviews 22(2):91-102.

10. Jayaweera D.M.A. (1981). Medicinal Plants- Indigenous and Exotic-Used in Ceylon-Part III, pp. 66-71. National Science Council of Sri Lanka. 47/5, Maitland Place, Colombo 07.

11. Pathirana P.S.K. \& Herat T.R. (2004). Comparative vegetative anatomical study of the genus Garcinia L. (Clusiaceae/ Guttiferae) in Sri Lanka. Ceylon Journal of Science (Biological Sciences) 32: 39-66.

12. Radford D.G., Carplo C.B. \& Santos G.A. (1974). Coconut varieties in the Philippines. Proceedings of the Fifth Annual Meeting the of Crop Science Society of the Philippines, May Naga City.

13. Bacon C.D. \& Baily C.D. (2006). Taxonomy and Conservation: A Case study from Chamaedorea allernans. Annals of Botany 98(4):755-763.

14. International Union for conservation of Nature (1997). Designing an optimum protected areas system for Sri Lanka's natural forests, Vol. 1 and 2, pp. X+299. Forest Department. Ministry of Forestry and Environment, Battaramulla. 